\title{
Physical chemistry research of a concrete dam with over 50 years of operation
}

\section{(Investigação físico-química de uma barragem de concreto com mais de 50 anos de operação)}

\author{
K. F. Portella ${ }^{1}$, A. Joukoski ${ }^{1}$, V. Swinka Filho ${ }^{1}$, M. A. Soares ${ }^{2}$, E. S. Ferreira ${ }^{2}$ \\ ${ }^{I}$ Instituto de Pesquisa para o Desenvolvimento, LACTEC, C. P. 19067, 81531-990, Curitiba, PR, Brasil. \\ ${ }^{2}$ Companhia Paranaense de Energia, R. José Izidoro Biazetto, 158, 81200-240 Curitiba, PR, Brasil \\ kfportella@pq.cnpq.br
}

\begin{abstract}
Guaricana hydroelectric power plant concrete dam, located in the South of Brazil, was investigated after 49 years of operation. A part of the mortar was altered to ettringite, and other by-products. The inner defects in the fracture and polished sample surfaces were detected by CT and SEM. The samples were extracted from two parts of the dam from top to valley. Elemental chemical composition and phases were determined by EDS and XRD analysis. The reservoir water showed that it was less aggressive to the concrete structure. Percolated dam water analyses revealed a mortar-mass loss of $3 \mathrm{~kg} /$ year. Onsite visual inspection, mechanical tests, and other usual forms of investigation confirmed concrete deterioration, such as leaching, stalactites and stalagmites formation, alkali-aggregate reaction and ettringite. Furthermore, mortar damage was detected in a particular area according to the dam depth, and autogenous healing of cracks were visible in some parts of the inspected galleries.
\end{abstract}

Keywords: concrete, water permeability, deterioration, alkali-aggregate reaction.

\section{Resumo}

A usina hidroelétrica Guaricana, localizada no sul do Brasil, foi investigada após 50 anos de sua operação. O estudo mostrou que uma parte da argamassa extraída dos testemunhos alterou para etringita e outros sub-produtos. Defeitos internos nas superfícies polidas e de fratura das amostras foram detectados por CT e MEV. As amostras foram extraídas de duas partes da barragem do topo ao vale. A composição elementar e as fases químicas foram determinadas por EDS e difração de raios X. Análises da água do reservatório mostraram ser pouco agressivas à estrutura de concreto. As análises da água percolada pela barragem revelaram uma perda de massa de $3 \mathrm{~kg} /$ ano. Inspeções visuais locais, testes mecânicos e outras análises confirmaram a deterioração parcial do concreto, tais como dissolução e formação de estalactites e estalagmites, reação álcali agregado e etringita. Danos na argamassa de algumas amostras foram detectados em uma área particular ao longo da profundidade de análise da barragem. Também foi verificada uma recuperação autógena das trincas em determinadas áreas das galerias de inspeção.

Palavras-chave: concreto, percolação da água, deterioração, reação álcali agregado.

\section{INTRODUCTION}

Typical problems associated with dam structures involve efflorescence, porosities, and surface irregularities such as construction, expansion and control joints, mechanical cracks, material aggregates, and continuous chemical attacks owing to water permeation and environmental pollution [1-3]. The immediate consequence on concrete and other associated materials (reinforcing steel and hydroelectric ferrous devices such as turbines and floodgates) is cement degradation, corrosion of ferrous materials, and concrete expansions owing to alkali-aggregate reaction (AAR) and other expansive byproducts. These damages contribute to the acceleration of the maintenance and substitution of several world dams, and their investigation involves multidisciplinary sciences, including geological, chemical, physical, thermal, civil, hydraulic, and materials and mechanical engineering.

Different techniques in various fields are used to investigate the performance and even the stability of dams. Each technique contributes to elucidate some of the deterioration mechanisms involved. One good example is the X-ray computer tomography (CT). CT is useful to evaluate porosity, cracks, heterogeneity, and voids in the concrete samples. In this technique, the image of a concrete sample is reconstructed from several projections obtained by using incident-penetrating X-rays [3-12].

On-site visual inspection is another technique used to investigate problems in concrete surfaces, such as cracks, efflorescence, desegregation, and leaching. However, care should be taken to avoid errors owing to any special pathological concrete causes.

AAR are thoroughly investigated by different techniques including scanning electron microscopy (SEM), simultaneous 
thermal analysis (STA), X-ray diffraction (XRD), and others [1-3, 11-12].

Portella et al. 2009 [13] and Pires (2009) [14], investigating rocks nearby the dam, by SEM and EDS, conclude that they have alkali reactivity expansion and they present nowaday $60 \%$ of residual alkali aggregate reactive potential.

Physicochemical analyses of concrete samples extracted from the dam, such as cement content, porosity index, specific mass, and XRD, presented good evidence regarding the causes of deterioration. The results indicate which regions of the dam are more damaged or affected by internal or external agent.

All the above-mentioned techniques, along with the mechanical properties and petrography of the concrete samples, were used to investigate the aged performance of Guaricana hydroelectric power plant (GHPP), located in the south of Brazil on Paraná state, after 50 years of operation.

GHPP was inaugurated in 1957 and has four electrical power generation groups. It was built with gravity concrete and is $87-\mathrm{m}$ long and 22-m high. Fig. 1 illustrates its downstream face. The reservoir retains natural water from Arraial River. The dam is located at a typical climate condition with temperature variations from $-4{ }^{\circ} \mathrm{C}$ in winter to $32{ }^{\circ} \mathrm{C}$ in summer.

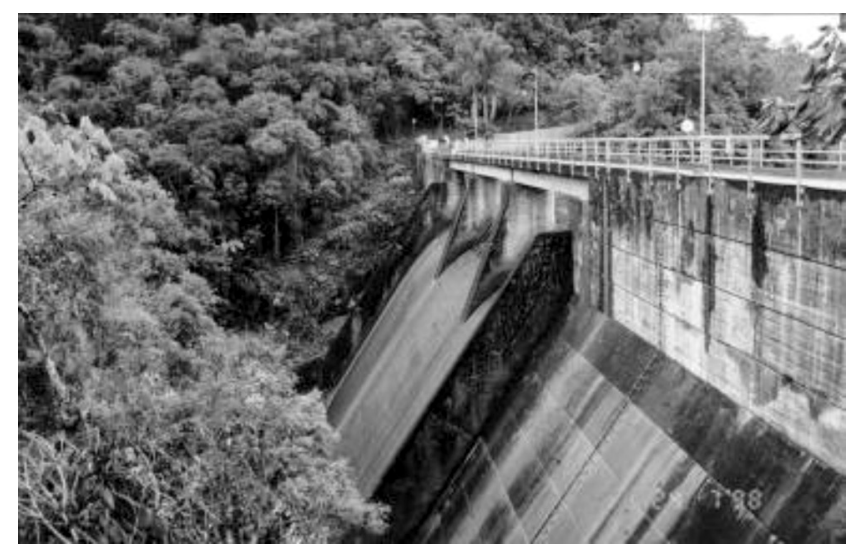

Figure 1: Downstream face of the Guaricana hydroelectric power plant dam.

[Figura 1: Face à jusante da barragem UHE Guaricana.]

\section{MATERIALS AND METHODS}

On-site visual inspection of the concrete at the surface and galleries of the dam was carried out. Fault occurrences and surface defects were registered using photographs. Tools and phenolphthalein alkali chemical indicator were used to verify the apparent resistance of the concrete, desegregation, emerged carbonation, acid attack, and for collecting the samples for testing.

SEM analyses were carried out in a Philips XL 30 with energy dispersive X-ray spectrometer system (EDS) facility. Polished and fractured surface of the concrete core samples were investigated after metallic coating by cathode sputtering.

CT was carried out in a $(5 \times 10) \mathrm{cm}^{2}$ core sample using a Gilardoni X-ray tomograph at $70 \mathrm{kV}$ and $2 \mathrm{~mA}$.
The inspection gallery, elevations, and partial schematic views are illustrated in Fig. 2. The figure also shows vertical lines from where the concrete samples were pneumatically extracted from top to valley in the center and left sides of the dam.

Compressive strength was developed in $(7.5 \times 15) \mathrm{cm}^{2}$ core samples with a universal test machine. The tests were carried out according to the methodology recommended by ASTM C39 [15].

Flexural tensile strength test was carried out on $(7.5 \times 15)$ $\mathrm{cm}^{2}$ core samples in accordance with the ASTM C496 [16].

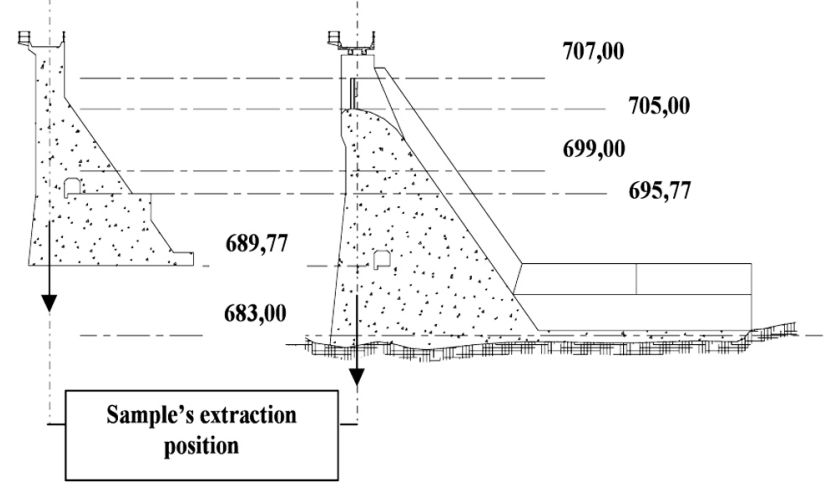

Figure 2: Schematic view of the dam Guaricana. The elevations are measured from sea level, in meters.

[Figura 2: Vista esquemática da barragem Guaricana. As quotas são medidas à partir do nível do mar, em $\mathrm{m}$.]

XRD phase identification in powder concrete core samples was carried out in a Philips X'PERT MPD instrument with Cuk $\alpha$ radiation from 5 to $90^{\circ}$ at $40 \mathrm{kV}$, $40 \mathrm{~mA}$, and $0.02 \%$. The chemical phases were identified using the Joint Committee on Powder Diffraction Standard (JCPDS) database.

Water was sampled from the reservoir surface and inspection gallery at a confluence of the drainage points. Subsequently, physicochemical analysis was carried out to verify the chemical composition of the river, and salt quantities were determined from the cement paste. Dionex Ion Chromatograph (IC) and Perkin-Elmer Atomic Absorption Spectrophotometer (AA) with Graphite Furnace in mortar, prepared by acid digestion, were used to investigate the chemical composition of water.

Furthermore, petrographic analysis by optical microscopy (OM) was carried out on parts of the concrete samples and aggregates in a thin-section mode.

\section{RESULTS AND DISCUSSIOM}

\section{Physicochemical water results}

The reservoir-water values were kept constant for at least 7 years, and showed that it is less aggressive to the concrete; however, it had caused some leaching [1] on the structure, as confirmed from the results of 1998 and 2005, presented 
in Table I. This is a potential hazard to the concrete owing to the strong disequilibrium salt conditions.

The alkali concentration in the reservoir water was found to be lower than that established by Taylor [3], to cause any AAR, i. e., the content of equivalent $\mathrm{Na}_{2} \mathrm{O}$ was found to be below $0.6 \%$. However, alkalis were constantly introduced by seepage into the structure owing to porosity and cracks, and their value was found to be less than $0.1 \%$.

Percolated water analyses revealed a mortar-mass loss of about $3 \mathrm{~kg} /$ year in the first assessment, in 1998. Out of the total mass loss, loss of $\mathrm{Ca}^{2+}$ ions was $1.3 \mathrm{~kg} /$ year and that $\mathrm{Na}^{+}$and $\mathrm{K}^{+}$ions was $1.7 \mathrm{~kg} /$ year. Furthermore, the concentration of other cement chemical constituents (Al, Si, $\mathrm{Fe}, \mathrm{Mg}$ ), soluble in water, was low. The insoluble salts in water-drain holes were not evaluated [8].

In the second investigation, the values obtained were lesser than those obtained from the first investigation. In this case, some drain-holes leaching points were observed, which stopped seepage [8].

Visual inspection of the surface of the concrete gallery confirmed the influence of leaching after 50 years, showing carbonation from cracks under stalactite and stalagmite forms. Some observed cracks were found to have stopping leach owing to the impurities in the reservoir water (clay materials), and principally, by precipitation of calcium carbonate, as shown in Fig. 3. These results correspond to the dormant cracks obtained by Edvardsen in samples exposed to similar conditions for shorter times [17]. The

Table I - Physicochemical results of the reservoir and percolated water from the inspection gallery at the confluence drain holes.

[Tabela I - Resultados físico químicos das águas do reservatório e percolada pela galeria de inspeção na confluência dos drenos.]

\begin{tabular}{|c|c|c|c|c|c|c|c|c|c|c|c|}
\hline $\mathrm{pH}$ & $\mathrm{Al}^{3+}$ & $\mathrm{Ca}^{2+}$ & $\mathrm{Fe}^{3+}$ & $\mathrm{Mg}^{2+}$ & $\mathrm{K}^{+}$ & $\mathrm{Na}^{+}$ & $\mathrm{Si}^{4+}$ & $\mathrm{Cl}^{-}$ & $\mathrm{NO}_{3}^{-}$ & $\mathrm{SO}_{4}^{2-}$ & TS* \\
\hline \multicolumn{12}{|c|}{ From reservoir water $(\mathrm{mg} / \mathrm{L})$} \\
\hline 6.70 & 0.30 & 0.60 & 0.45 & 0.80 & 0.60 & 1.70 & 5.50 & 3.40 & 0.83 & 0.90 & 36 \\
\hline \multicolumn{12}{|c|}{ From percolated water $(\mathrm{mg} / \mathrm{L})-1998$} \\
\hline 11.62 & 1.40 & 56.00 & --- & 0.01 & 29.90 & 45.50 & 4.50 & 1.00 & 0.73 & 2.00 & --- \\
\hline \multicolumn{12}{|c|}{ From percolated water $(\mathrm{mg} / \mathrm{L})-2005$} \\
\hline 6.90 & 0.20 & 15.00 & 2.70 & 2.00 & 7.75 & 11.80 & 7.10 & 3.17 & 2.48 & 1.32 & 114 \\
\hline
\end{tabular}
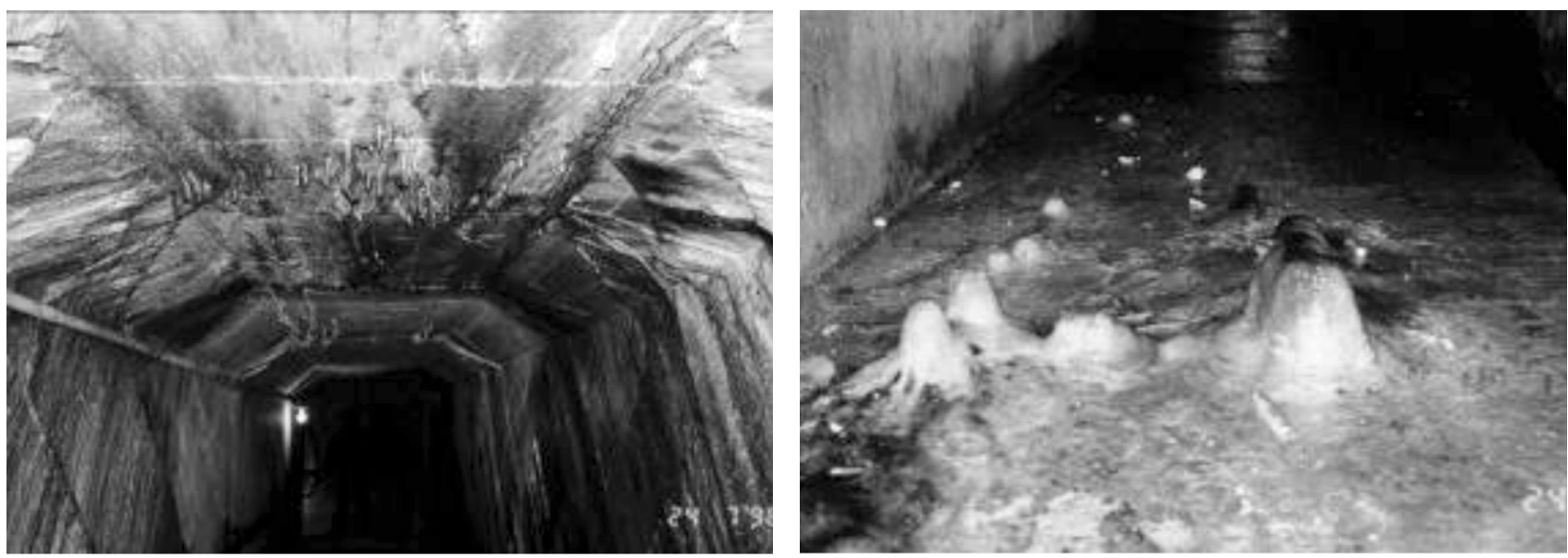

Figure 3: Emerged carbonation as stalactites and stalagmites from concrete cracks in the inspection gallery.

[Figura 3: Carbonatação apresentada nas formas de estalactites e estalagmites a partir de trincas no concreto de dentro da galeria de inspeção.]

Table II - XRF result from stalactites and stalagmites samples.

[Tabela II - Resultados da FRX das amostras de estalactites e estalagmites.]

\begin{tabular}{lllllllllll}
\hline & $\mathrm{CaO}$ & $\mathrm{MgO}$ & $\mathrm{Fe}_{2} \mathrm{O}_{3}$ & $\mathrm{SiO}_{2}$ & $\mathrm{Al}_{2} \mathrm{O}_{3}$ & $\mathrm{TiO}_{2}$ & $\mathrm{Na}_{2} \mathrm{O}$ & $\mathrm{K}_{2} \mathrm{O}$ & Other & $\mathrm{LF}$ \\
\hline Values (\%) & 54.65 & 0.09 & 0.05 & 0.18 & 0.05 & 0.01 & 0.03 & 0.03 & 1.20 & 43.71 \\
\hline LF: loss of fire. & & & & & & & & & &
\end{tabular}


aspect of the cracks (geographic maps) indicates possible expansive reactions.

XRF and XRD patterns of the samples extracted from these structures showed $54.65 \%$ of $\mathrm{CaO}$ or $\mathrm{CaCO}_{3}$ in calcite form as the main phase, as shown in Table II.

The surfaces of the concrete core samples revealed imperfections, such as voids and desegregation of the particulate materials (dislodged with probe) in specific

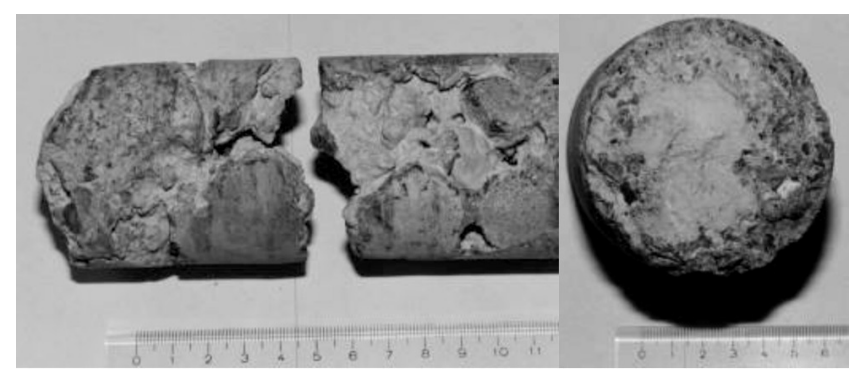

Figure 4: Concrete core samples from the GHPP dam.

[Figura 4: Amostras de testemunhos de concreto da barragem Guaricana.]
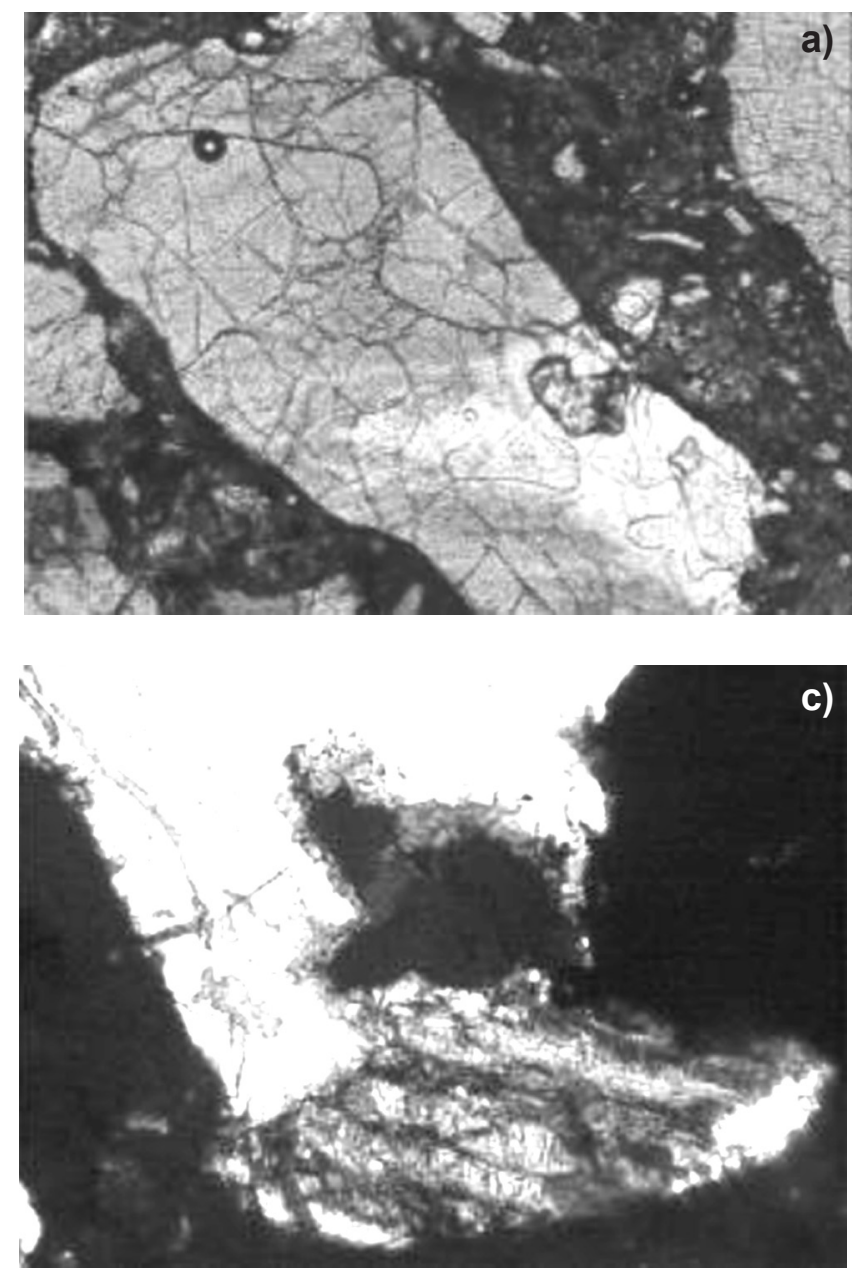

Figure 5: OM feldspar images: a) microcracks under natural and b) polarized light; c) boundary reactions; and d) AAR.

[Figura 5: Imagens de feldspato por MO: a) microtrincas sob sob luz natural; b) luz polarizada; c) reações nas interfaces; d) reação álcali agregado, RAA.]

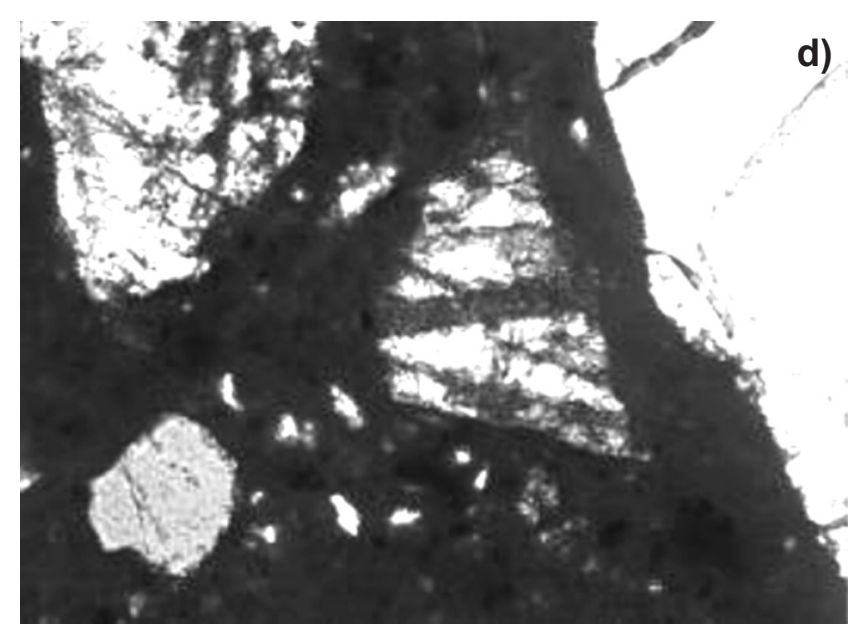

regions of the depth of the dam, mainly between elevations of 688 and $700 \mathrm{~m}$, as shown in Fig. 4. The concrete deterioration was found to be owing to leaching and formation of chemical by-products. However, because of concrete fragility and superficial defect, it was impossible to develop mechanical tests in this kind of samples.

XRD patterns from $5^{\circ}$ to $90^{\circ}$ of the concrete core sample powders revealed the presence of ettringite, calcite, and other concrete chemical phases.

Petrographic analysis showed granite and basalt as the major constituents of the concrete mass. The mineralogy examination revealed the presence of quartz, alkali feldspar, pyroxene, muscovite, and other constituents.

OM aggregate images from concrete structures shown in Fig. 5 reveal surface deterioration of alkali feldspar, such as microcracks, gel reactions, and boundary reactions, corroborating with the results obtained $[13,14]$.

The concrete alteration was confirmed by SEM images of polished and fractured concrete sample surfaces, as shown in Figs. 6-8. The images revealed cracks as well as gel and ettringite byproduct crystals in the pores and voids. Fig. 6

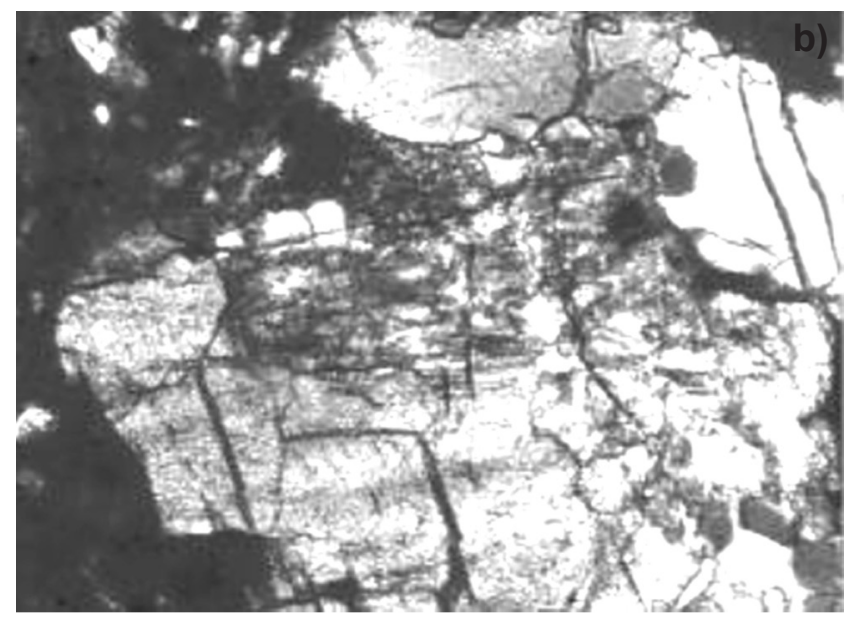



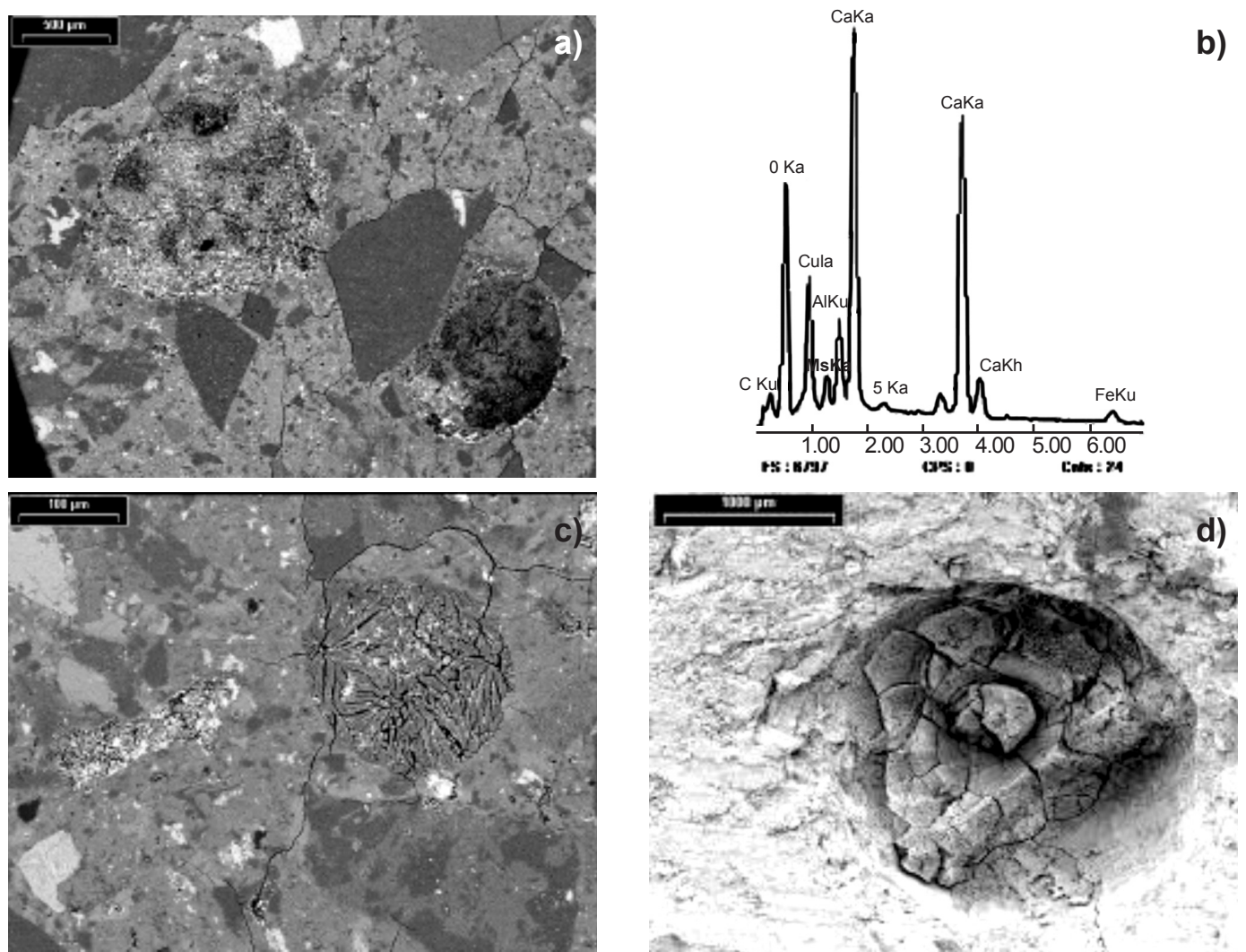

Figure 6: SEM micrographs of the a) polished concrete surface and b) EDS analysis of the void ( $X$ region); c) ettringite phase (arrow); and d) gel.

[Figura 6: Micrografias por MEV da: a) superficie polida do concreto e b) análise por EDS do vazio (região X); c) fase etringita (seta) e d) gel.]
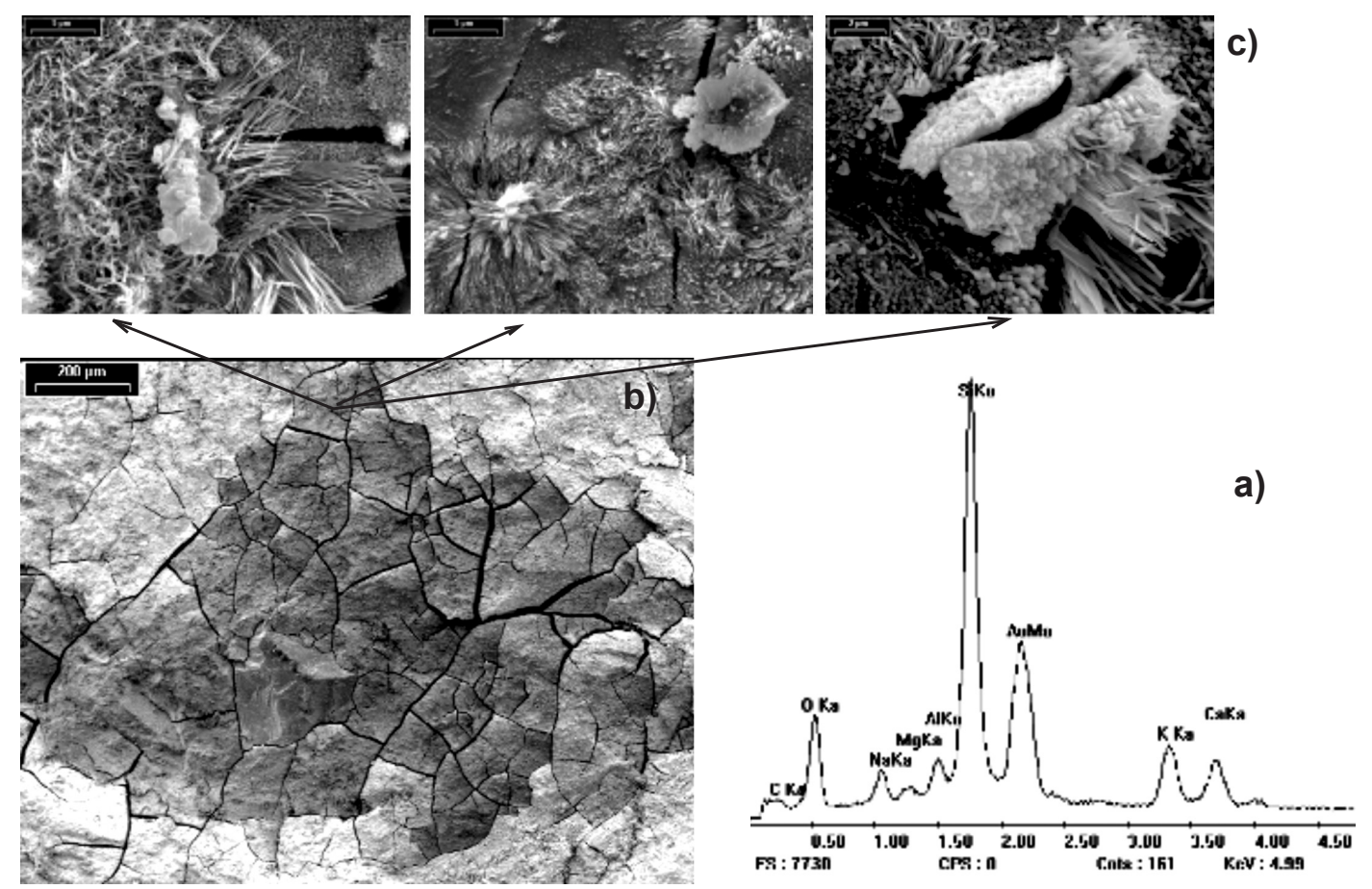

Figure 7: Massive gel grated concrete core fractured surface. (a) EDS elemental analysis; (b) SEM image of the surface of the concrete sample; and c) detailed crystal images.

[Figura 7: Gel gretado na superfície de fratura do concreto: a) análise elementar por EDS; b) imagem por MEV da superfice da amostra do concreto; e c) imagem dos cristais em detalhes.] 

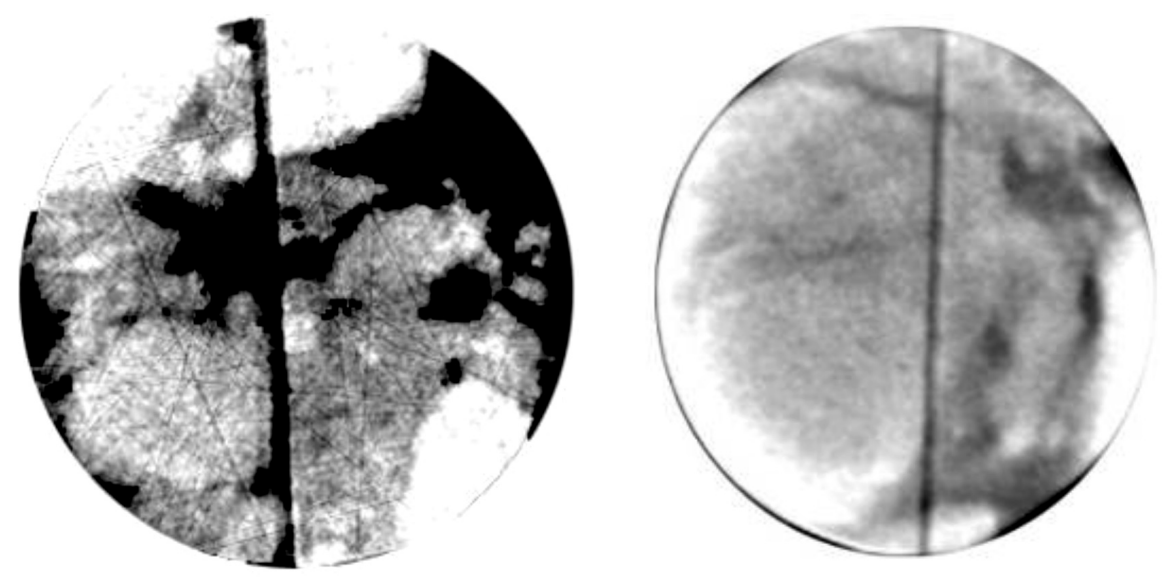

Figure 8: CT images. The darkest areas are the possible water leaching path.

[Figura 8: Imagens por tomografia computadorizada, CT. As áreas mais escuras representam possíveis caminhos de percolacão de água.]

Table III - Mechanical test results of concrete core samples from the dam GHPP.

[Tabela III -Resultados dos testes mecânicos dos testemunhos de concreto da barragem Guaricana.]

\begin{tabular}{cccccc}
\hline Test & Samples & Mean & $\begin{array}{c}\text { Standard } \\
\text { deviation }\end{array}$ & $\begin{array}{c}\text { Maximum } \\
\text { value }\end{array}$ & $\begin{array}{c}\text { Minimum } \\
\text { value }\end{array}$ \\
\hline Tang, elastic modulus (GPa) & 12 & 34.58 & 10.03 & 50.00 & 18.20 \\
Flexural tensile strength (MPa) & 24 & 3.68 & 0.78 & 5.15 & 2.55 \\
Compressive strength (MPa) & 24 & 38.36 & 7.38 & 54.50 & 26.40 \\
\hline
\end{tabular}

also shows the images of the chemical elemental analysis of the crystals, showing $\mathrm{Ca}, \mathrm{Al}, \mathrm{O}, \mathrm{C}, \mathrm{S}$, ettringite crystals (arrow), and gel phases [18].

Elemental analysis of the crystals by EDS revealed crack pattern in several parts of the samples, as illustrated in Fig. 7. This result demonstrates an equivalent proportion of $\mathrm{Ca}^{2+}$ ions and alkalis, which is typical of the gel composition. The details of this grated surface are also shown by increasing the magnification.

Tomographic reconstruction images of different sections of the sample showed large discontinuities in all crosssections of the sample, as shown in Fig. 9, by contrast resolution. The darkest areas in the image signify the voids. The core samples were cut (vertical black line) to insure image interpretation. Both the images were reconstructed from different sample parts, which confirmed water percolation.

Concrete chemical analyses through hardened cement content analyses revealed an original cement, aggregate, and sand composition of around 1:1:6 in the determined constructed blocks and 1:2:8 in other blocks. Cement consumptions were variable between 200 and $320 \mathrm{~kg} / \mathrm{m}^{3}$.

Alkali salt analyses from these samples demonstrated an average of $2.8 \mathrm{wt} \%$ for $\mathrm{Na}_{2} \mathrm{O}$ and $3.3 \mathrm{wt} \%$ for $\mathrm{K}_{2} \mathrm{O}$. These results could be contributed to expansive gel formation, as Taylor formulae [3].

The results of water absorption content were between 5.6 and $6.5 \%$, and the specific mass was around $2,500 \mathrm{~kg} / \mathrm{m}^{3}$.

The mechanical test values are presented in Table III for the compressive strength as a function of the depth of the dam, and these values do not signify concrete degradation.

All the mechanical test results revealed a concrete mass in good condition for the main purpose, but as seen in Figure 8 , some parts in the core samples extracted from 697 to 694 $m$ depth of the dam demonstrated real sign of degradation, and could not be tested.

\section{CONCLUSIONS}

Recent technologies were used to evaluate the GHPP dam's concrete structure deterioration: CT images were useful for the visualization of the inner defects, such as waterpercolation path and voids. XRD, SEM, and EDS pointed out the possible coexistence of AAR and ettringite acicular crystal phase in some concrete voids observed mainly between 697 and $694 \mathrm{~m}$ depth of the concrete dam. IC along with AA results was important to determine the chemical composition of the mortar structure and the reservoir and percolated water. Mechanical tests indicated that the

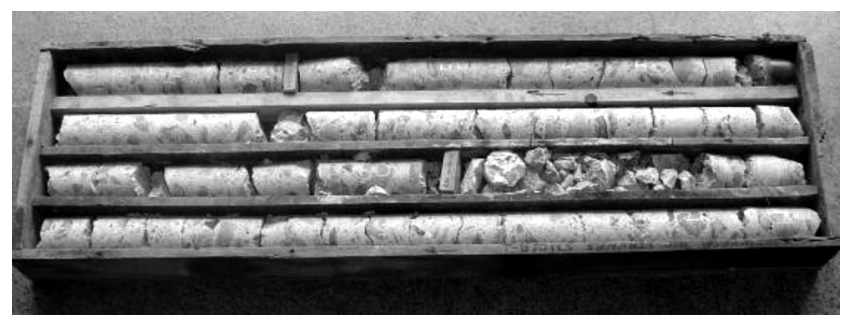

Figure 9: Core samples from 697 to $694 \mathrm{~m}$ depth of the dam. [Figura 9: Testemunhos de concreto da barragem desde a quota 697 até $694 \mathrm{~m}$.] 
concrete mass was in good condition for the main purpose, but some parts at the depth of the dam (mainly between 697 and $694 \mathrm{~m}$, as mentioned earlier) were not tested owing to the degradation of the superficial core. Nevertheless, all these phenomena detected do not seem to be deleterious to the dam concrete at this stage of the reaction process, as no other structure manifestation was observed.

\section{ACKNOWLEDGEMENTS}

The authors acknowledge COPEL, CNPq/PQ and CNPq/PIBITI, and LACTEC for the financial support, and all people that contributed to these results.

\section{REFERENCES}

[1] A. Shayan A, J. Grimstad, Cement Concr. Res. 36 (2006) 371.

[2] I. Biczok, Translated by J. D. Asensi, Corrosion y Proteccion del hormigon, Urmo. Spain (1981).

[3] H. F. W. Taylor, Cement Chemistry, Academic Press, London, UK (1990).

[4] I. Fernandes, F. Noronha, M. Teles, Mater. Charact. 53 (2004) 295.

[5] T. Katayama, Cement Concr. Res. 40 (2010) 643.

[6] E. Pecoraro, M. R. Davolos, M. Jafelicci Jr, J. Braz. Chem. Soc. 6 (1995) 341.

[7] R. Mendes, W. C. Godoi, K. F. Portella, J. C. A. Galvão, P. Martins, V. Swinka Filho, K. De Geus, Insigth (Northampton) 51 (2009) 832.
[8] K. F. Portella, C. M. Garcia, M. P. Cantão, E. Esmanhoto, E. S. Ferreira, J. R. G. Nogueira, R. Robert, M. M. Elias, V. Swinka Filho, J. C. Biondi, $21^{\text {st }}$ Annual United States Soc. Dams Lecture Series, Denver, USA 1 (2001) 733.

[9] C. Ayora, S. Chinchon, A. Aguado, F. Guirado. Cement Concr. Res. 28 (1998) 1223.

[10] K. E. Kurtis, P. J. M. Monteiro, J. T. Brown, W. MeyerIlse, Cem. Concr. Res. 8 (1998) 411.

[11] K. L. Scrivener, J. F. Young, Mechanisms of chemical degradation of cement-based systems, E \& FN SPON, London, UK (1997).

[12] P. J. M. Monteiro, C. Y. Pichot, K. Belkebir, C. Ozick, Materials science of concrete, Am. Ceram. Soc., USA (1998).

[13] K. F. Portella, A. Joukoski, L. A. de Lacerda, R. B. Boszczowski, R. R. Zorzi, B. L. Medeiros, E. C. Ferreira, J. L. Bronholo, M. A. Soares, K. O. Pires, Relatório técnico, RT LAME.0.2009-R0 (2009). 73 p

[14] K. O. Pires, Diss. Mestrado, UFPR, Curitiba, PR, Brazil (2009).

[15] ASTM C39/C39M: Standard Test Method for Compressive Strength of Cylindrical Concrete Specimens, Philadelphia, USA (1999).

[16] ASTM C 496: Standard Test Method for Standard Test Method for Splitting Tensile Strength of Cylindrical Concrete Specimens, Philadelphia, USA (1996).

[17] C. Edvardsen, ACI Mater. J. 96 (1999) M56.

[18] ASTM C 1084: Standard Test Method for Portlandcement content of hardened hydraulic-cement concrete, Philadelphia, USA (1992).

(Rec. 09/03/2011, Ac. 16/10/2011) 